\title{
MANAGEMENT REGIMES WITHIN SYNTAXA OF SEMI-NATURAL GRASSLANDS IN WEST BULGARIA
}

\author{
Nikolay VELEV ${ }^{1, *} \&$ Kiril VASSILEV ${ }^{1}$
}

\begin{abstract}
This study focuses on mesic and xeric grasslands of mostly secondary origin, and that are influenced by human activity. Mesic grasslands are traditionally used for hay-making, and xeric ones for pastures. Over the last 20 years, livestock farming in Bulgaria has significantly declined so that less grass is needed. Many types of grasslands are no longer used and lots of abandoned fields can be found nowadays in Bulgaria. The analyses in this study are based on 868 relevés collected on xeric and mesic grasslands according to the methodological approach of BraunBlanquet. As a result, five alliances within two classes are recognized: the class Festuco-Brometea, represented by three alliances, namely Cirsio-Brachypodion pinnati, Chrysopogono-Danthonion calycinae and Festucion valesiacae, and the class Molinio-Arrhenatheretea, represented by two alliances, namely Arrhenatherion elatioris and Cynosurion crista$t i$. The majority of the managed grasslands are situated in close proximity to settlements. Most of the abandoned areas (30\%) are found within Cirsio-Brachypodion alliance. These grasslands are characterized by the highest values of total cover of vegetation. They are located in the most distant and least accessible areas. If use is not resumed, all the abandoned grasslands will be under threat of extinction in the near future. At the same time, many arable lands have been abandoned and turned into grasslands by the processes of secondary succession.

Keywords: classification, grazing, mowing, ordination, species diversity, syntaxonomy, vegetation.

Izvleček

V raziskavi smo se osredotočili na mezična in kserična travišča večinoma sekundarnega nastanka, ki so pod vplivom človekovih aktivnosti. Mezična travišča se tradicionalno uporabljajo za seno, kserična pa kot pašniki. V Bolgariji je živinoreja v zadnjih 20 letih močno upadla in je potreba po krmi manjša. S številnimi tipi travišč ne gospodarijo več in danes je v Bolgariji moč najti številne opuščene površine. V analizi smo zbrali 868 vegetacijskih popisov kseričnih in mezičnih travišč, narejenih z Braun-Blanquetovo metodo. Uvrstili smo jih v pet zvez in dva razreda: razred Festuco-Brometea, ki ga predstavljajo tri zveze Cirsio-Brachypodion pinnati, Chrysopogono-Danthonion calycinae in Festucion valesiacae in razred Molinio-Arrhenatheretea z dvema zvezama Arrhenatherion elatioris in Cynosurion cristati. Večina vzdrževanih travišč se nahaja v bližini naselij. Večino opuščenih površin (30\%) uvrščamo v zvezo Cirsio-Brachypodion in za te travnike je značilno, da imajo največjo skupno pokrovno vrednost in se nahajajo v najbolj oddaljenih, težko dostopnih območjih. Če jih ne bomo ponovno začeli uporabljati, bodo v bližnji prihodnosti izginili. Obenem se opuščajo tudi številne obdelovalne površine, ki se spreminjajo $\mathrm{v}$ travnike $\mathrm{v}$ procesu sekundarne sukcesije.

Ključne besede: klasifikacija, paša, košnja, ordinacija, vrstna pestrost, sintaksonomija, vegetacija.
\end{abstract}

\section{INTRODUCTION}

Traditionally, Bulgarian semi-natural grasslands are not improved, either by treatment with artificial fertilisers and pesticides, by or reseeding. The grasslands with mesic character are cut for hay, whereas those with xeric character are used as pastures. The significant decline in farming intensity over the past 20 years has resulted in a reduced demand for grass, by farmers for their livestock.

\footnotetext{
${ }^{1}$ Institute of Biodiversity and Ecosystem Research, Bulgarian Academy of Sciences, 2 Gagarin Str., 1113 Sofia, Bulgaria. E-mail: nikolay.velev@abv.bg; kiril5914@abv.bg

* Corresponding author: nikolay.velev@abv.bg
} 
Abandonment leads to scrub, forest and bracken (Pteridium aquilinum) encroachment within grasslands. This is known as secondary succession, i.e. the gradual replacement of one plant community by another. Such regeneration of the natural vegetation in the same place after human or natural disturbances is also described in literature as "demutation", "demutational changes", "regenerative changes", "secondary succession" and "progressive succession" (Schmithüsen 1961, Shennikov 1964, Bykov 1967, 1970, Rabotnov 1978, Barbour et al. 1980). Meshinev et al. (2000), Meshinev (2001), Apostolova \& Meshinev (2001) and Yordanova (2001) reported active regeneration of the potential natural vegetation within grasslands that were no longer under a pasture or mowing regime. Less accessible pastures and those of higher altitudes are more often abandoned (Nikolov 2010, Vassilev et al. 2011), while managed grasslands are situated mainly close to settlements. Typically, the latter grasslands have low species diversity, a compacted substrate because of the intensive trampling, and considerable presence of ruderal species (Velev 2005). A diminished need for hay results in abandonment of many hay-meadows. Some of them are now used as pastures or have been abandoned completely. Shifting the management type from hay-making to grazing favours an increased presence of xeric and ruderal species, as has been recorded by Vassilev et al. (2011) in West Bulgaria. They state that abandoned pastures are dominated by mesic species, while grazed pastures are dominated by mesoxeric species. The invasion of forest and shrub vegetation into grasslands is highlighted as one of the major negative consequences of the abandonment of meadows and pastures (Meshinev et al. 2005, Schrautzer et al. 2009, Hegedüšová \& Senko 2011). Bush encroachment causes a decline in the grazing capacity of grasslands (Smit 2004). Abandoned grasslands are subject changes in their floristic composition, ecology and syntaxonomy (Meshinev et al. 2000, 2009, Jantunen 2003, Stránská 2004, Velev \& Apostolova 2008, Ruprecht et al. 2009, Rusina \& Kiehl 2010, Házi et al. 2011, Priede 2011). When such changes occur in vegetation, some grassland types may locally disappear (Stančić 2008, Hegedüšová \& Senko 2011). These changes in the vegetation are also reflected in other components of biodiversity, such as insects (Söderström et al. 2001, Wiezik et al. 2011, Šumpich \& Konvička 2012), birds (Nikolov 2010), etc.

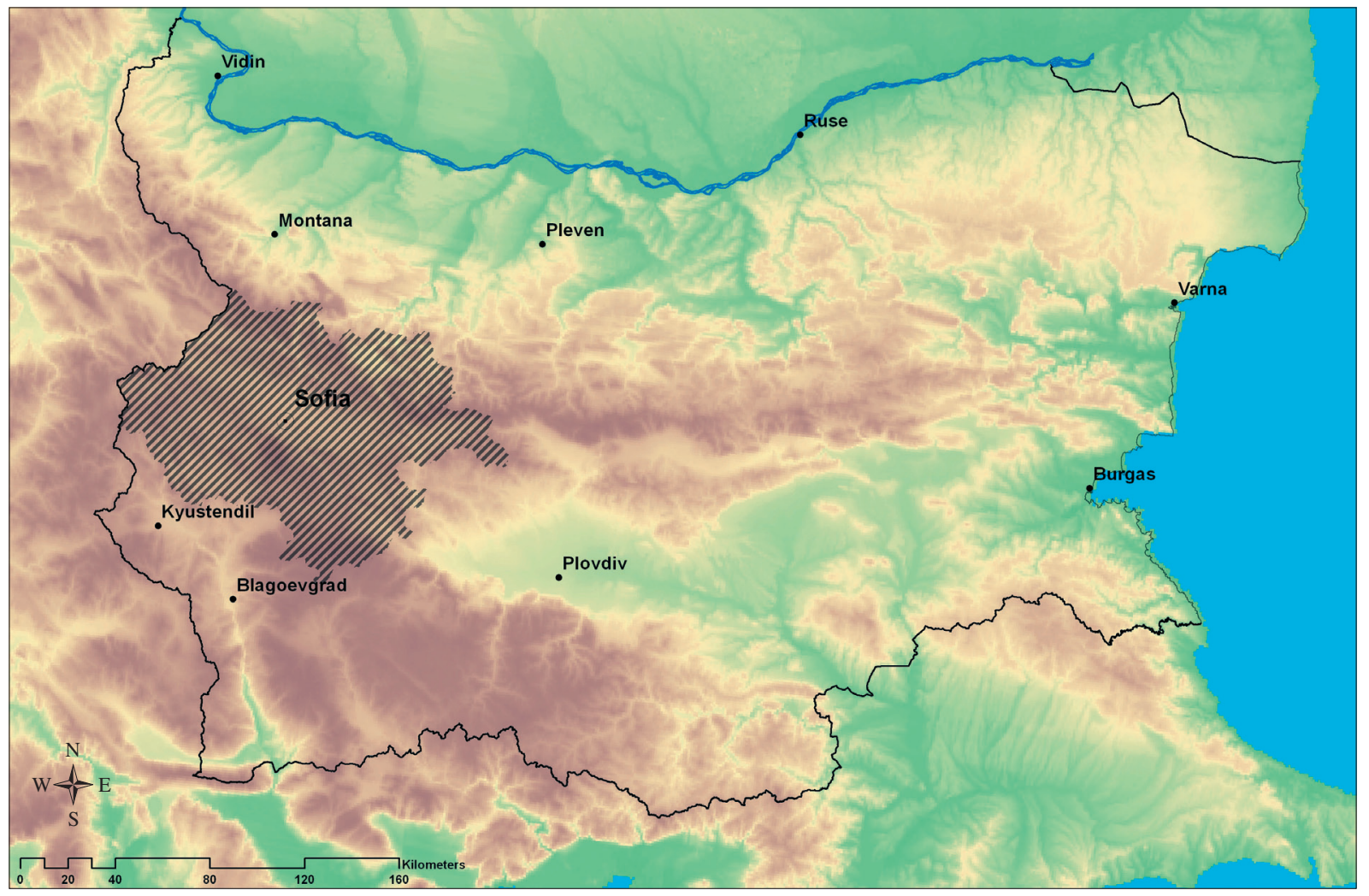

Figure 1: Map of Bulgaria. The study area is shaded.

Slika 1: Karta Bolgarije, obravnavano območje je osenčeno. 
The aim of this study is to find: 1 . Which syntaxa occur in West Bulgarian dry and mesic semi-natural managed grasslands? 2. What is the species diversity within these grasslands? 3 . What types of management are these grasslands subjected to?

\section{MATERIAL AND METHODS}

\subsection{Study AREA}

The study area is situated in the central part of West Bulgaria (Figure 1). The total study area is more than $10,000 \mathrm{~km}^{2}$. The research was focused on the mesic and xeric grasslands, which are mostly secondary and are influenced by human activity. According to the climatic zones of Bulgaria, the study area is classified as temperatecontinental and transitional-continental (Velev 2002). The climate in this region is characterized by warm summers and cold winters and by high annual amplitudes of air temperature. The average annual temperature is $10.0{ }^{\circ} \mathrm{C}$ with a minimum in January and maximum in July. The average annual precipitation is $571 \mathrm{~mm}$ with a minimum in February and a maximum in June (Lieth et al. 1999). An ombrothermic climatic diagram from Sofia observatory is shown in Figure 2. The bedrock of mesic grasslands is mainly silicate, whereas that of the xeric grasslands is mainly limestone.

\subsection{Field SAMPling}

Dry and mesic semi-natural managed grasslands from the study area in West Bulgaria were sampled. The sampled localities were chosen randomly. We tried to set the sample plots so as to uniformly cover the entire study area. The management types of grasslands as grazing, mowing and abandonment were recorded. In the analyses, three dummy variables were used to indicate the absence or presence of these three management types. The analyses were based on 868 relevés collected according to the methodological approach of Braun-Blanquet (Braun-Blanquet 1965, Westhoff \& van der Maarel 1973, Mueller-Dombois \& Ellenberg 1974). All relevés were collected within four vegetation growing seasons (2007-2010). The sample plots were square with area of $16 \mathrm{~m}^{2}$, which is recommended for grasslands (Knapp

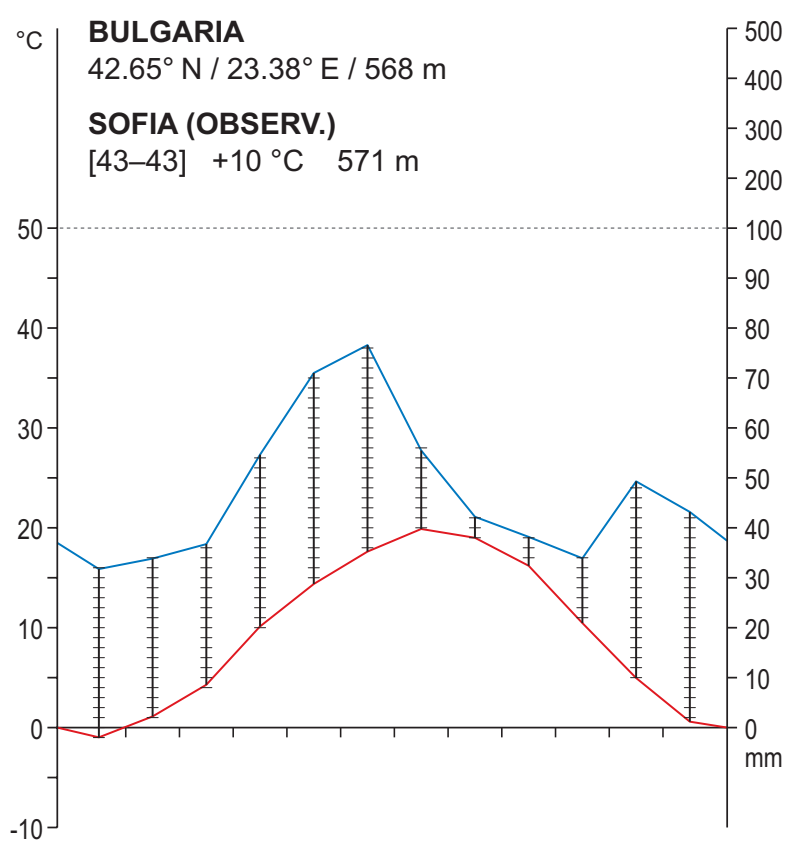

Figure 2: Ombrothermic climatic diagram for the study area, according to Lieth et al. (1999).

Slika 2: Ombrotermični klimatski diagram obravnavanega območja, po Lieth et al. (1999).

1984, Kent \& Coker 1992, Chytrý \& Otýpková 2003). The expanded Braun-Blanquet combined scale (Barkman et al. 1964, van der Maarel 1979, Parolly 2003) was used for the estimation of species' cover/abundance. All 868 relevés were stored in a TURBOVEG database (Hennekens \& Schaminèe 2001) and in the Bulgarian vegetation database (Apostolova et al. 2012). The taxonomy of species follows primarily Kozhuharov (1992). Taxa not included in this source were determined using Delipavlov \& Cheshmedjiev (2003) and Assyov \& Petrova (2012).

\subsection{DATA ANALYSIS}

Numerical classification was performed by TWINSPAN (Hill 1979) incorporated in the JUICE 7.0 software package (Tichý 2002). Three pseudospecies cut levels $(0,5,25)$ were used in the analyses. The same software was used for calculating some syntaxa attributes, such as the number of relevés, total species number, average species number, average Whittaker $\beta$-diversity, average positive fidelity, sharpness index and uniqueness index. The quality of the classified syntaxa was expressed by the indices of sharp- 
ness and uniqueness. Analyses of these indicators express the well-defined and poorly defined syntaxa (Chytrý \& Tichý 2003). Sharpness and uniqueness indices were calculated on the basis of 100 randomly selected relevés. The species in the synoptic table (Table 1) were represented by two indicators: fidelity measure, expressed by the phi-coefficient multiplied by 100 (Chytrý et al. 2002), and constancy, expressed in percentage. For the fidelity calculation, all relevé groups were standardized to equal size (Tichý \& Chytrý 2006). The phi-values were verified by Fisher's exact test $(P<0.001)$, in order to eliminate the statistically insignificant phi-coefficients. The $\beta$-diversity for each syntaxon was calculated on the basis of 100 randomly selected relevés. Indirect Gradient Analysis (DCA) was applied using the CANOCO version 4.55 software (ter Braak \& Šmilauer 2002) in order to interpret ecologically the vegetation differentiation. A preliminary DCA analysis established that the gradient length of first axis is higher than four standard deviation units. Large differences between vegetation units are best described by unimodal response models (ter Braak \& Prentice 1988) and this is the reason why DCA was chosen. Rare species were downweighted in the analyses, because DCA ordination is sensitive to species that occur even in few samples (ter Braak 1987). The data were normalized by "square root transformation" (McDonald 2008, Osborne 2010). The variables such as management regime, total cover and Shannon index were passively projected onto the first two DCA axes in order to explore any existing patterns in the studied grassland vegetation. The Shannon index is a widely used index for characterizing the species diversity in a plant community by taking into account the species richness and evenness (Clarke \& Warwick 2001, Tichý \& Holt 2006). The Shannon indices of the studied vegetation units were summarized and presented as box-and-whiskers plots. The observed differences were tested for statistical significance by Mann-Whitney U-test.

\section{RESULTS}

\subsection{Classification ANd ORdinAtion}

As a result of the TWINSPAN classification, five vegetation groups were distinguished. These clusters are identified as five alliances within two classes: class Festuco-Brometea Br.-Bl. \& Tüxen ex
Soó 1947 , represented by three alliances, namely Cirsio-Brachypodion pinnati Hadač \& Klika ex Klika 1951, Chrysopogono-Danthonion calycinae Kojić 1959 and Festucion valesiacae Klika 1931, and class Molinio-Arrhenatheretea Tüxen 1947, represented by two alliances, namely Arrhenatherion elatioris Luquet 1926 and Cynosurion cristati Tüxen 1947. The recognized syntaxa are in compliance with Klika (1931, 1951), Kojić (1959), Chytrý (2007), Chytrý et al. (2007), Hájková et al. (2007) and Sanda et al. (2008).

Festuco-Brometea and Molinio-Arrhenatheretea grasslands are well distinguished in the DCA ordination diagram (Figure 3). The eigenvalue of the first axis (0.591) shows a good dispersion of the sample plots along it. Its gradient length is 4.539 and explains $8.10 \%$ of the total inertia. The main gradient (first axis) could be related to moisture. The variance explained by the second DCA axis (0.291) is a small portion (3.99\%) of the total inertia in the data set (7.293). The gradient length of the second axis is 3.967. It is closely related to soil acidity. Soil pH increases between the alliances Cirsio-Brachypodion and Festucion valesiacae (Figure 3). The Festuco-Brometea class is represented by 368 relevés, and Molinio-Arrhenatheretea by 500 relevés. The Arrhenatherion alliance is best represented (by 298 relevés), followed by Festucion valesiacae (by 236 relevés), while the least represented is the alliance Chrysopogono-Danthonion (by only 10 relevés). All the alliances are shown in a synoptic table with phi-coefficients (Table 1). The best separated alliance within our database is Cirsio-Brachypodion. The Sharpness index (19.97) and the Uniqueness index (1.0) values prove its distinctness within the data set (Table 2).

\subsection{Management PRACtices}

The vegetation within the Festuco-Brometea class is found only in pastures, while some of the grasslands classified in this class are abandoned. Although some of the dry grasslands are mesic enough to be mown (like Cirsio-Brachypodion), we did not observe any mowing activities during this study. Molinio-Arrhenatheretea grasslands are used both for grazing and mowing (Figure 4). Usually these grasslands are cut once per year. Mowing is the prevailing management type within mesic grasslands, even within the Cynosurion alliance, which is traditionally managed as pastures. The majority of dry grasslands are used 


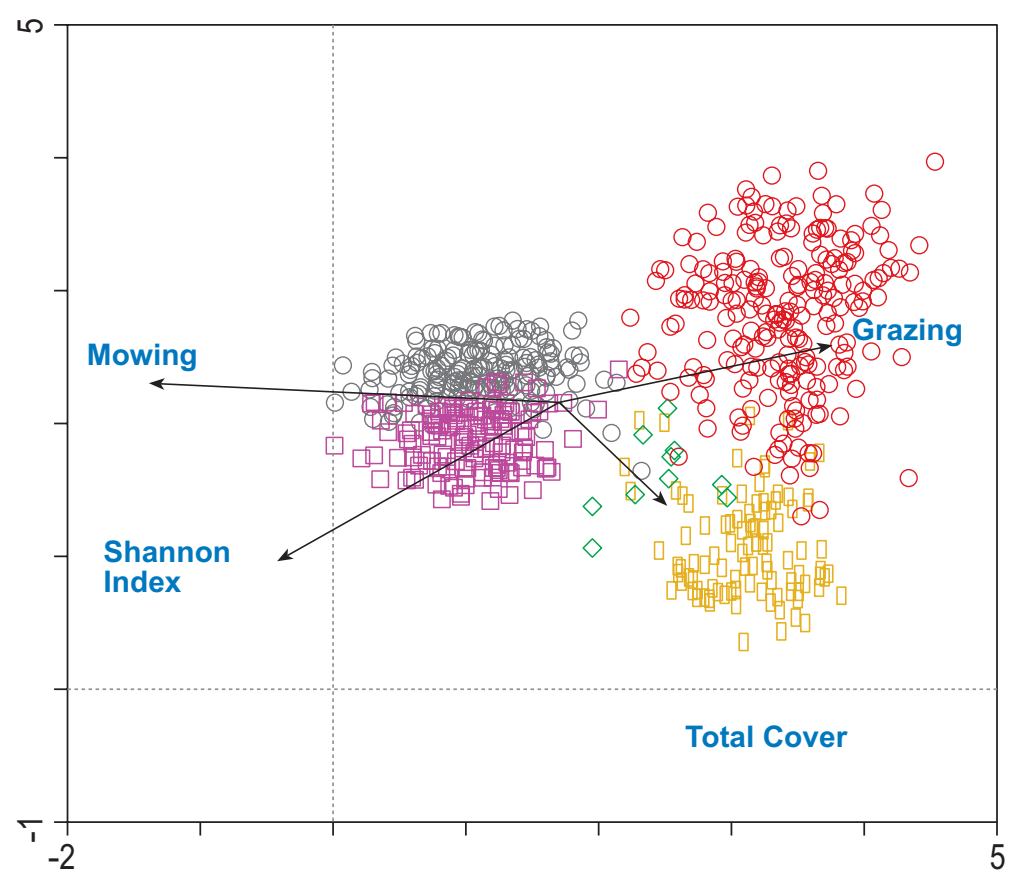

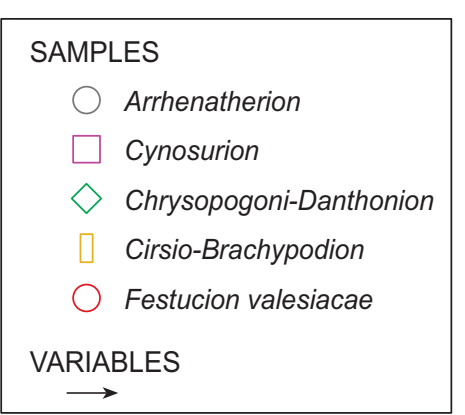

Figure 3: Ordination diagram of relevés along the first two DCA axes. Variables concerning management regime, total cover of vegetation and Shannon diversity index are passively projected onto the ordination space.

Slika 3: Ordinacijski diagram popisov vzdolž prvih dveh DCA osi. Spremenljivke o načinu gospodarjenja, skupni pokrovnosti in Shannonov indeks pestrosti so pasivno prikazane $\mathrm{v}$ ordinacijskem prostoru. as pastures (89\%), while $11 \%$ of them are abandoned. Mesic grasslands are mainly used for hay (43\%). Grazing only and combined usage (both grazing and mowing) of grasslands occur in $22 \%$

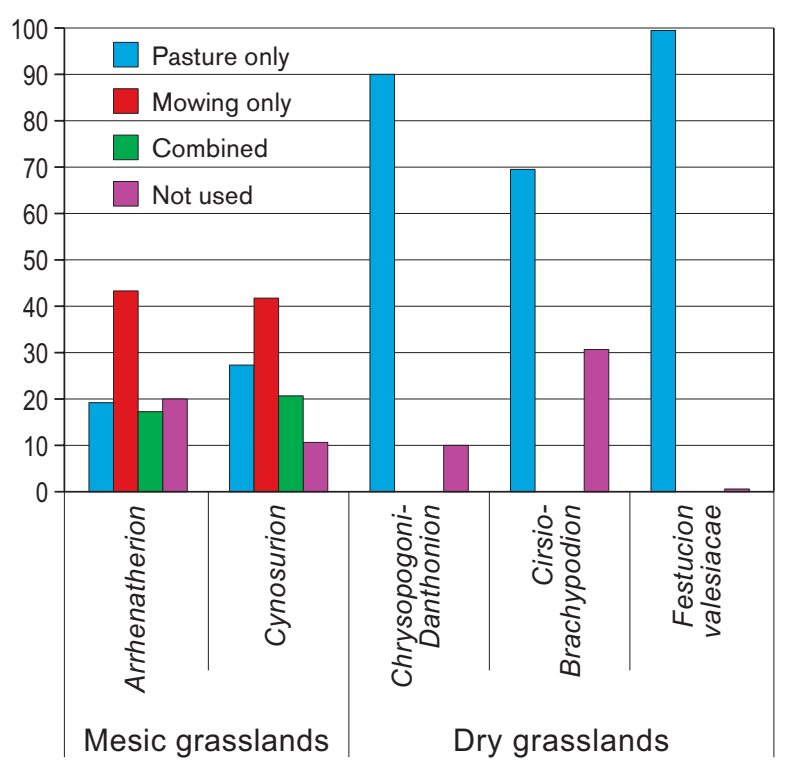

Figure 4: Management regimes within the considered alliances. Percentage values of the management regimes recorded in the relevés sampled within each alliance are given.

Slika 4: Načini gospodarjenja v posameznih zvezah. Prikazane so odstotne vrednosti različnih načinov gospodarjenja, zabeleženih v vzorčenih popisih posamezne zveze. and $19 \%$ of the mesic grasslands, respectively. Abandoned mesic grasslands represent 16\% of their total area. The highest percentage $(30 \%)$ of abandoned lands and the highest values of total cover were found within the Cirsio-Brachypodion alliance (Figure 4), followed by the Arrhenatherion alliance with $20 \%$ of abandoned lands. The lowest proportion of abandoned grasslands was found within the Festucion valesiacae alliance less than $0.5 \%$.

\subsection{SPEGIES DIVERSITY}

The dry grasslands of the Festucion valesiacae alliance is the syntaxon with the highest species richness within the analyzed dataset, presenting also the highest $\beta$-diversity values. The vegetation of mesic grasslands is more homogenous than that of dry grasslands, and has the lowest $\beta$-diversity values. The Shannon species diversity index is highest within the Cynosurion alliance indicating the highest community complexity (Figure 3 ). As a result, the Cynosurion alliance has the highest average species number and at the same time the lowest $\beta$-diversity value. The Festucion valesiacae alliance shows the opposite pattern, with the lowest average species number but the highest $\beta$-diversity value. Within both alliances, average species number is negatively related to $\beta$-diversity (Table 2 ). 


\section{DISCUSSION}

Changes in management type lead to changes in species composition of grasslands (Jantunen 2003, Farris et al. in press), and also the course of vegetation succession (Velev \& Apostolova 2008). Grazing management of Arrhenatherion grasslands, for example, increases the species diversity (Figure 5), as it reduces the strong dominant role of Arrhenatherum elatius. The potential of grazing for biodiversity enhancement and restoration of pastures in this way is reported by Metera et al. (2010) and Wrage et al. (2011). In contrast, the Cynosurion alliance shows increased species diversity within its abandoned grasslands (Fig. 5). We consider this as a short-term effect after the abandonment of grasslands. The diversity loss within abandoned meadows may be driven by different mechanisms depending on the life history strategy of the dominant species (Csergo" et al. 2013). Mesic grasslands are characterized by low values of $\beta$-diversity, but high Shannon index values (Table 2, Figure 5). The highest values of total cover were found within the abandoned lands, mostly within Cirsio-Brachypodion pinnati alliance. These are among the most distant and least accessible grasslands. Most of the managed grasslands are situated in close proximity to settlements, as is the case for the mesic grasslands of the Arrhenatherion and Cynosurion alliances. Unsurprisingly, the remoteness of grasslands from settlements is negatively related to the intensity of their management and vice versa. Cirsio-Brachypodion grasslands are among the most distant ones from villages and this explains the high percentage of abandoned lands within this alliance (Figure 4). If no longer managed, all the abandoned grasslands in the study area will end up in diverse shrub and forest communities. Nearly $14 \%$ of the grasslands are abandoned within the study area. Grazing and mowing of Bulgarian grasslands has gradually declined in the past 20 years, and in many places has ceased completely (see also Apostolova \& Meshinev 2006). The absence of regular mowing and grazing within these grasslands has put them under threat of extinction. Shrubs and trees are known to be more competitive than herbaceous species and all abandoned lands in the study area are gradually invaded by shrub and forest vegetation. Similar processes occur in many other localities in Bulgaria (Meshinev et al. 2000, 2005, Velev 2005). The abandonment, as well as the overgrazing of pastures are considered to have a negative impact on biodiversity and should be avoided (Metera et al. 2010). There are places where the development of shrub vegetation is so advanced that the former grasslands have completely transformed into shrub communities (information obtained from local people). Nowadays, a lot of mesic pastures are converted into hay meadows or are abandoned. At the same time, much arable land has been abandoned and become grassland by the processes of demutation. Such secondary succession on abandoned croplands is also called oldfield succession (Barbour et al. 1980). Usually, these are Arrhenatherum elatius dominated plant communities classified within Arrhenatherion alliance. Such lands are located close to villages and now are used for hay-making or as pastures.

As a rule, in the study area the grazing is of low intensity and intensive grazing almost completely ceased over 20 years ago. Typically, Cynosurion grasslands used to be managed as pastures, but it is notable that mowing now prevails within Cynosurion alliance (Figure 4). This is in accordance with the decreased livestock numbers and decreased need of pasture lands, as in general, farmers now keep only one or two grazing animals. Meshinev et al. (2005) and Apostolova \& Meshinev (2006) also indicate mowing as the predominant management type within the Cynosurion alliance in Bulgaria. According to Horvat et al. (1974), the Cynosurion vegetation on the Balkans is managed in a different way as compared to Central Europe, where it is managed as pastures and in many cases is improved by manuring. Bulgarian semi-natural grasslands are completely unimproved. Depending on the management practices, Cynosurion type grasslands may be developed from other vegetation types as Arrhenatherion or Calthion (Zuidhoff et al. 1995, Dierschke 1997, Hájková et al. 2007). Traditionally, the meadows of the Arrhenatherion alliance are used for hay-making. Today, due to the decreased demand for hay, many of these meadows are abandoned or used as pastures. The alliance with the most abandoned land (30\%) is the Cirsio-Brachypodion pinnati. Abandoned grasslands in Bulgaria within this alliance have also been recorded by Pedashenko et al. (2013). These communities contain some rare species of high conservation value on national and international level, such as Balkan endemics (Chamaecytisus calcareus, Sesleria latifolia, Silene roemeri), species included in the national Biological Diversity Act (Lilium jankae, L. martagon), species included in 
Arrhenatherion

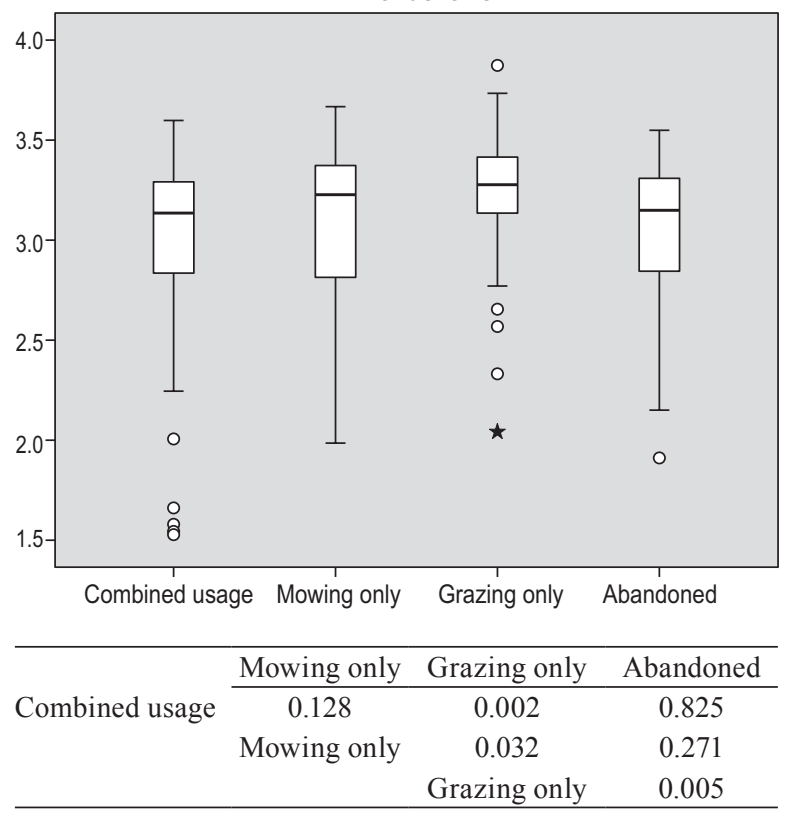

Cirsio-Brachypodion

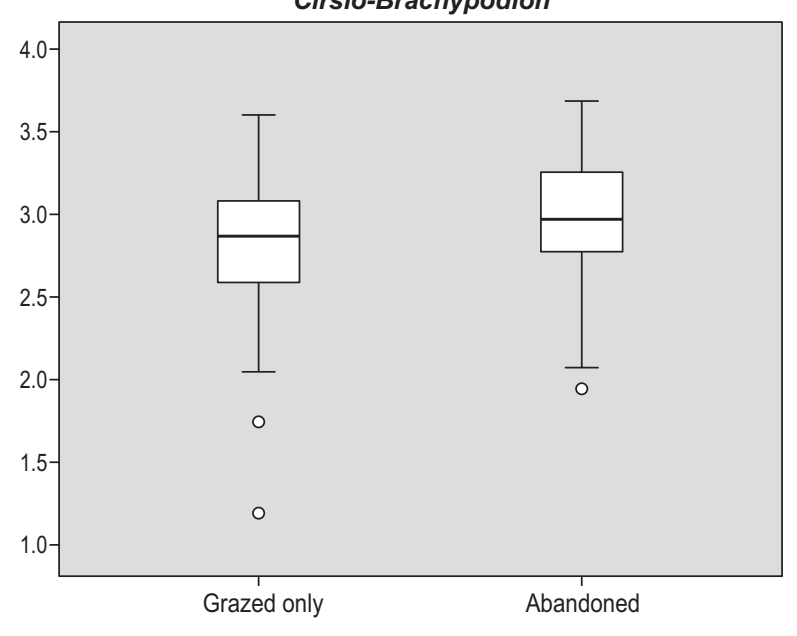

\begin{tabular}{lc}
\hline \multirow{2}{*}{ Combined usage } & Abandoned \\
\cline { 2 - 2 } & 0.101 \\
\hline
\end{tabular}
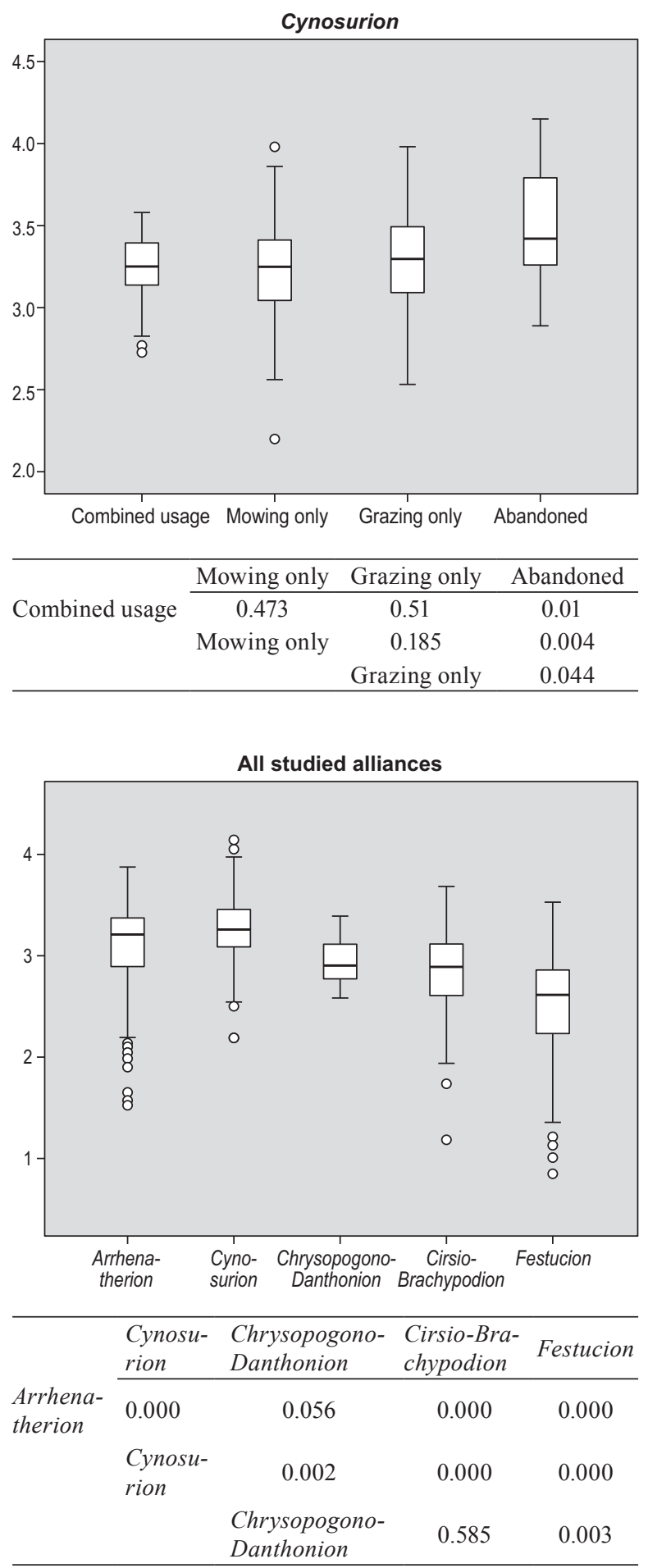

Figure 5: Box-and-whiskers plots of Shannon index. Results are tested for statistical significance by Mann-Whitney U-test. The significance levels of $\mathrm{P}$-values are presented below every diagram. The observed differences are statistically significant if $\mathrm{P}<0.05$. Box-and-whiskers plots are not presented for the Festucion valesiacae and the Chrysopogono-Danthonion, because within them mostly or only grazing management practice has been recorded.

Slika 5: Shannonov indeks, prikazan z grafom škatla z brki. Rezultate smo statistično testirali z Mann-Whitneyevim U testom. Stopnje značilnosti so prikazane pod vsakim grafom. Razlike so statistično značilne pri $P<0,05$. Škatla $z$ brki ni prikazana za zvezi Festucion valesiacae in Chrysopogono-Danthonion, ker se ta travišča gospodari večinoma s pašo. 
the Red Data Book of the Republic of Bulgaria and in the Annex II of the Directive 92/43/EEC (Echium russicum) and species included in the Red List of Bulgarian vascular plants (Thesium linophyllon, Tragopogon balcanicus) (Vassilev et al. 2012). At the present time, these grasslands are under serious threat from shrub and tree invasion. The regular management of these semi-natural grasslands is considered to be an excellent tool for restoration, sustainability and protection from extinction. Grazing is suggested as an intervention to prevent the invasion of shrubs in open landscapes (Metera et al. 2010). Extensive grazing and control of shrub encroachment are good practices in the management of xerophytic and mesophytic grasslands in West Bulgaria (Vassilev et al. 2011). According to Begon et al. (2006), a moderate grazing regime will introduce the necessary heterogeneous environment, without causing pasture deterioration and strong compaction of the substrate, thus increasing grasslands species richness.

\section{ACKNOWLEDGEMENT}

The authors are grateful to H. Pedashenko for configuring and preparing the map. We also express our sincere thanks to the reviewers and the editor, whose suggestions improved the manuscript considerably. Special thanks to Laura Sutcliffe for linguistic editing and IAVS for supporting the editing financially through a project grant to EDGG.

\section{REFERENCES}

Apostolova, I. \& Meshinev, T. 2001: Karta na rastitelnostta na visokoplaninskata bezlesna zona na Priroden park "Vitosha" (Vegetation map of the high-mountain treeless zone in Vitosha Nature Park). In: Temniskova, D. (ed.), Proceedings of Sixth National Conference of Botany, Sofia, pp. 241-252.

Apostolova, I. \& Meshinev, T. 2006: Classification of seminatural grasslands in Northeastern Bulgaria. Annali di Botanica Nuova Serie 6: 29-52.

Apostolova, I., Sopotlieva, D., Pedashenko, H., Velev, N. \& Vasilev, K. 2012: Bulgarian Vegetation Database: historic background, current status and future prospects. Biodiversity \& Ecology 4: 141-148.
Assyov, B. \& Petrova, A. (eds.) 2012: Conspectus of the Bulgarian vascular flora. Distribution maps and floristic elements. 4th ed. BBF, Sofia, 489 pp.

Barbour, M., Burk, J. \& Pitts, W. 1980: Terrestrial plant ecology. Benjamin/Cummings, Menlo Park, Calif., 604 pp.

Barkman, J., Doing, H. \& Segal, S. 1964: Kritische Bemerkungen und Vorschläge zur quantitativen Vegetationsanalyse. Acta Botanica Neerlandica 13: 394-419.

Begon, M., Townsend, C. \& Harper, J. 2006: Ecology. From individuals to ecosystems. Blackwell Scientific Publications, Oxford, 746 pp.

Braun-Blanquet, J. 1965: Plant sociology: The study of plant communities.Hafner, London, 439 pp.

Bykov, B. 1967: Geobotanicheskaya terminologiya. (Geobotanical terminology). Naouka, Alma-Ata, $167 \mathrm{pp}$.

Bykov, B. 1970: Vvedenie v fitocenologiu. (Introduction to Phytocoenology). Naouka, AlmaAta, 231 pp.

Chytrý, M. 2007: Festucion valesiacae Klika 1931. - In: Chytrý, M. (ed.). 2007. Vegetation of the Czech Republik 1. Grassland and heathland vegetation. Akademia, Prague, pp. 409-425.

Chytrý, M. \& Otýpková, Z. 2003: Plot sizes used for phytosociological sampling of European vegetation. Journal of Vegetation Science 14: 563-570.

Chytrý, M. \& Tichý, L. 2003: Diagnostic, constant and dominant species of vegetation classes and alliances of the Czech Republic: a statistical revision. Folia Facultatis Scientiarium Naturalium Universitatis Masarykianae Brunensis, Biologia 108: 1-231.

Chytrý, M., Tichý, L., Holt, J. \& Botta-Dukát, Z. 2002: Determination of diagnostic species with statistical fidelity measures. Journal of Vegetation Science 13: 79-90.

Chytrý, M., Hoffmann, A. \& Novák, J. 2007: (Festuco-Brometea). - In: Chytrý, M. (ed.): Vegetation of the Czech Republik 1. Grassland and heathland vegetation. Akademia, Prague, pp. 371-468.

Clarke, K. \& Warwick, R. 2001: Changes in marine communities: an approach to statistical analysis and interpretation. 2nd ed. PRIMER, Plymouth, $177 \mathrm{pp}$.

Council Directive 92/43/EEC of 21 May 1992 on the conservation of natural habitats and of wild fauna and flora. URL: http://ec.europa. 
eu/environment/nature/legislation/habitatsdirective/index_en.htm.

Csergő, A. M., Demeter, L. \& Turkington, R. 2013: Declining diversity in abandoned grasslands of the Carpathian Mountains: do dominant species matter? PLoS One 8: e73533. DOI: 10.1371/journal.pone.0073533.

Delipavlov, D. \& Cheshmedzhiev, I. (eds.) 2003: Opredelitel na rastenyata v Bulgaria. (Key to the Plants of Bulgaria). Academic Press Agrarian University, Plovdiv, 591 pp.

Dierschke, H. 1997: Molinio-Arrhenatheretea (E 1). Kulturgrasland und verwandte Vegetationstypen. Teil 1: Arrhenatheretalia. Wiesen und Weiden frischer Standorte. FlorSoz, Göttingen, $74 \mathrm{pp}$.

Farris, E., Secchi, Z., Rosati, L. \& Filigheddu, R.: Are all pastures eligible for conservation? A phytosociological survey of the SardinianCorsican Province as a basic tool for the Habitats Directive. Plant Biosystems (in press). DOI: 10.1080/11263504.2013.778911.

Hájková, P., Hájek, M., Blažková, D., Kučera, T., Chytrý, M., Řezníčková, M., Šumberová, K., Černý, T., Novák, J. \& Simonová, D. 2007: Meadows and mesic pastures (MolinioArrhenatheretea). In: Chytrý, M. (ed.): Vegetation of the Czech Republic Vol., 1: Grassland and heathland vegetation. Academia, Prague, pp. 165-280.

Házi, J., Bartha, S., Szentes, S., Wichmann, B. \& Penksza, K. 2011: Seminatural grassland management by mowing of Calamagrostis epigejos in Hungary. Plant Biosystems 145: 699-707.

Hegedüšová, K. \& Senko, D. 2011: Successional changes of dry grasslands in southwestern Slovakia after 46 years of abandonment. Plant Biosystems 145: 666-687.

Hennekens, S. \& Schaminée, J. H. J. 2001: TURBOVEG, a comprehensive data base management system for vegetation data. Journal of Vegetation Science 12: 589-591.

Hill, M. 1979: TWINSPAN - a FORTRAN for arranging multivariate data in an ordered two-way table by classification of individuals and attributes. Cornell University, Ithaca, $45 \mathrm{pp}$.

Horvat, I., Glavač, V. \& Ellenberg, H. 1974: Vegetation Südosteuropas. Fischer, Stuttgart, $766 \mathrm{pp}$.

Jantunen, J. 2003: Vegetation changes in a seminatural grassland during mowing and grazing periods. Annales Botanici Fennici 40: 255-263.
Kent, M. \& Coker, P. 1992: Vegetation description and analysis. A practical approach. John Wiley \& Sons, New York, 336 pp.

Klika, J. 1931: Studien über die xerotherme Vegetation Mitteleuropas. I. Die Pollauer Berge im südlichen Mähren. Beihefte zum Botanischen Centralblatt. 2. Abteilung, 47: 343-398.

Klika, J.1951: Xerothermní travinná společesnstva v Českém Středohoří. (Fytocenologická studie.). Rozpravy České Akademie Věd, Vědy Mathematické, Prúrodní 60(25): 1-47.

Knapp, R. 1984: Sample (relevé) areas (distribution, homogeneity, size, shape) and plot-less sampling. In: Knapp, R. (ed.), Handbook Vegetation Science 4. Junk, The Hague, pp. 101-119.

Kojić, M. 1959: Zastupljenost, uloga i značaj đipovine (Chrysopogon gryllus Trin.) u livadskim fitocenozama Zapadne Srbije. (Representation, role and importance of Chrysopogon gryllus Trin. of meadow phytocoenoses of Western Serbia) Arhiv za poljoprivredne nauke, Poljoprivredni fakultet u Zemunu, Beograd 12: 75-118.

Kozhuharov, S., (ed.). 1992: Opredelitel na visshite rastenia $\mathrm{v}$ Bulgaria. (Field guide to the vascular plants in Bulgaria). Naouka \& Izkoustvo, Sofia, $788 \mathrm{pp}$.

Lieth, H., Berlekamp, J., Fuest, S. \& Riediger, S. 1999: Climate diagram world atlas. Backuys Publishers, Leiden, CD-ROM.

McDonald, J. 2008: Handbook of biological statistics. Sparky House Publishing, Baltimore, Maryland, 319 pp.

Meshinev, T. 2001: Varhu nyakoi dinamichni procesi v savremennata rastitelnost na Bulgaria (On some dynamic processes in Bulgaria's vegetation today). In: Temniskova, D. (ed.): Proceedings of Sixth National Conference of Botany, Sofia, pp. 235-240.

Meshinev, T., Apostolova, I., Georgiev, V., Dimitrov, V., Petrova, A. \& Veen, P. 2005: Grasslands of Bulgaria. Final report on the National Grasslands Inventory Project - Bulgaria, 2001-2004. Dragon 2003 Publishers, Sofia, $104 \mathrm{pp}$.

Meshinev, T., Apostolova, I., Kachaunova, E., Velchev, V. \& Bondev, I. 2000: Flora and plant communities. In: Popov, A. \& Meshinev, T. (eds): High-mountain treeless zone of the Central Balkan National Park. Biological diversity and problems of its conservation. BSBCP, Sofia, pp. 1-337. 
Meshinev, T., Apostolova, I., Petrova, A. \& Georgiev, V. 2009: Grassland in North-Eastern Bulgaria - tradition and changes. In: Veen, P., Jefferson, R., de Smidt, J. \& van der Straten, J. (eds), Grasslands in Europe of high nature value. Zeist: KNNV Publishing, pp. 246-255.

Metera, E., Sakowski, T., Słoniewski, K. \& Romanowicz, B. 2010: Grazing as a tool to maintain biodiversity of grassland - a review. Animal Science Papers and Reports 28: 315-334.

Mueller-Dombois, D. \& Ellenberg, H. 1974: Aims and methods of vegetation ecology. John Wiley \& Sons, New York, 547 pp.

Nikolov, S. C. 2010: Effects of land abandonment and changing habitat structure on avian assemblages in upland pastures of Bulgaria. Bird Conservation International 20: 200-213.

Osborne, J. 2010: Improving your data transformations: Applying the Box-Cox transformation. Practical Assessment, Research \& Evaluation, 15(12): 1-9. URL: http://pareonline. net/getvn.asp?v=15\&n=12.

Parolly, G. 2003: Towards common standards in phytosociological papers submitted to the Turkish Journal of Botany: A Letter from the Editor. Turkish Journal of Botany 27: 163-165.

Pedashenko, H., Apostolova, I., Boch, S., Ganeva, A., Janišová, M., Sopotlieva, D., Todorova, S., Ünal, A., Vassilev, K., Velev, N. \& Dengler, J. 2013: Dry grasslands of NW Bulgarian mountains: first insights into diversity, ecology and syntaxonomy. Tuexenia 33: 309-346.

Priede, A. 2011: Phytosociology and dynamics of calcareous grasslands in Kemeri National Park, Latvia. Estonian Journal of Ecology 60: 284-304.

Rabotnov, T. 1978: Fitocenologia. (Phytocoenology). Publ. House of the Moscow University, Moscow, 384 pp.

Ruprecht, E., Szabo, A., Enyedi. M. Z. \& Dengler, J. 2009: Steppe-like grasslands in Transylvania (Romania): Characterisation and influence of management on species diversity and composition. Tuexenia 29: 353-368.

Rusina, S. \& Kiehl, K. 2010: Long-term changes in species diversity in abandoned calcareous grasslands in Latvia. Tuexenia 30: 467-486.

Sanda, V., Öllerer, K. \& Burescu, P. 2008: The Phytocoenoses of Romania. Syntaxonomy, structure, dynamics and development. Edit. Ars Docendi, Bucharest, 570 pp.

Schmithüsen, J. 1961: Allgemeine Vegetationsgeographie. Walter de Gruyter \& Co, Berlin, $262 \mathrm{pp}$.
Schrautzer, J., Jansen, D., Breuer, M. \& Nelle, O. 2009: Succession and management of calcareous dry grasslands in the Northern Franconian Jura, Germany. Tuexenia 29: 339-351.

Shennikov, A. 1964: Vvedenie v geobotaniku (Introduction to Geobotany). Publ. House of the Leningrad University, Leningrad, 447 pp.

Smit, G. N. 2004: An approach to tree thinning to structure southern African savannas for longterm restoration from bush encroachment. Journal of Environmental Management 71: 179-191.

Söderström, B., Svensson, B., Vessby, K. \& Glimskär, A. 2001: Plants, insects and birds in semi-natural pastures in relation to local and landscape factors. Biodiversity and Conservation 10: 1839-1863.

Stančić, Z. 2008: Classification of mesic and wet grasslands in northwest Croatia. Biologia 63: 1089-1103.

Stránská, M. 2004: Successional dynamics of Cynosurus pasture after abandonment in Podkrkonoší. Plant Soil and Environment 50: 364-370.

Šumpich, J. \& Konvička, M. 2012: Moths and management of a grassland reserve: regular mowing and temporary abandonment support different species. Biologia 67: 973-987.

ter Braak, C. 1987: Ordination. In: Jongman, R., ter Braak, C. \& van Tongeren, O. (eds): Data analysis in community and landscape ecology. Pudoc, Wageningen, pp. 91-173.

ter Braak, C. \& Prentice, C. 1988: A Theory of gradient analysis. Advances in Ecological Research 18: 271-317.

ter Braak, C. \& Šmilauer, P. 2002: CANOCO Reference Manual and CanoDraw for Windows User's Guide: Software for Canonical Community Ordination (version 4.5). Microcomputer Power, Ithaca, New York, 351 pp.

Tichý, L. 2002: JUICE, software for vegetation classification. Journal of Vegetation Science 13: 451-453.

Tichý, L. \& Chytrý, M. 2006: Statistical determination of diagnostic species for site groups of unequal size. Journal of Vegetation Science 17: 809-818.

Tichý, L. \& Holt, J. 2006: JUICE program for management, analysis and classification of ecological data. Program manual. Brno, Masaryk University, 98 pp. URL: http://www. sci.muni.cz/botany/juice/jc06_man.htm (accessed 2009-02-11). 
van der Maarel, E. 1979: Transformation of cover-abundance values in phytosociology and its effect on community similarity. Vegetatio 39: $97-114$.

Vassilev, K., Apostolova, I. \& Pedashenko, H. 2012: Festuco-Brometea in Western Bulgaria with an emphasis on Cirsio-Brachypodion pinnati. Hacquetia 11: 227-248.

Vassilev, K., Pedashenko, H., Nikolov, S. C., Apostolova, I. \& Dengler, J. 2011: Effect of land abandonment on the vegetation of upland semi-natural grasslands in the Western Balkan Mts., Bulgaria. Plant Biosystems 145: 654-665.

Velev, N. 2005: Notes on the dynamics of grassy vegetation in the Lovech region. Phytologia Balcanica 11: 207-211.

Velev, N. \& Apostolova, I. 2008: Successional changes of Nardus stricta communities in the Central Balkan Range (Bulgaria). Phytologia Balcanica 14: 75-84.

Velev, St. 2002: Climatic regioning. In: Kopralev, I. (ed.): Geography of Bulgaria. ForCom, Sofia, pp. 155-156.

Westhoff, V. \& van der Maarel, E. 1973: The Braun-Blanquet approach. In: Whittaker, R. (ed.), Classification of plant communities. Junk, The Hague, pp. 287-399.
Wiezik, M., Wieziková, A. \& Svitok, M. 2011: Vegetation structure, ecological stability, and low-disturbance regime of abandoned dry grasslands support specific ant assemblages in Central Slovakia. Tuexenia 31: 301-315.

Wrage, N., Strodthoff, J., Cuchillo, H. M., Isselstein, J. \& Kayser, M. 2011: Phytodiversity of temperate permanent grasslands: ecosystem services for agriculture and livestock management for diversity conservation. Biodiversity and Conservation 20: 3317-3339.

Yordanova, M. 2001: Dinamika na rastitelnostta varhu izostaveni pasishta $\mathrm{v}$ Zapadni Rodopi (Vegetation dynamics on the abandoned pastures in West Rhodopes). In: Temniskova, D. (ed.), Proceedings of Sixth National Conference of Botany, Sofia, pp. 339-344.

Zuidhoff, C., Rodwell, S. \& Schaminée, H.J. 1995: The Cynosurion cristati Tx. 1947 of Central, Southern and Western Europe: a tentative overview, based on the analysis of individual relevés. Annali di Botanica 53: 25-47.

Received 2. 3. 2013

Accepted 3. 1. 2013

Co-ordinating editor: Ioannis Tsiripidis 
Table 1: Fidelity (phi coefficients) and relative constancy synoptic table of the alliances of grasslands in West Bulgaria. Only statistically significant fidelity values $(P<0.001$; Fisher's exact test $)$ are presented. Phi-values are multiplied by 100 . Taxa which have phi< 30 have been omitted.

Tabela 1: Navezanost (fi koeficient) in sinoptična tabela $\mathrm{z}$ relativno stalnostjo zvez travišč $\mathrm{v}$ zahodni Bolgariji. Prikazane so samo statistično značilne vrednosti navezanosti ( $\mathrm{P}<0,001$; Fisherjev natančni test). Fi vrednosti smo pomnožili s 100. Taksoni s fi vrednostjo, manjšo od 30, niso prikazani.

\begin{tabular}{|c|c|c|c|c|c|c|c|c|c|c|}
\hline \multirow{2}{*}{$\begin{array}{l}\text { Syntaxa recognized } \\
\text { Number of relevés } \\
\text { Fidelity }(x 100) / \text { Constancy }\end{array}$} & \multicolumn{2}{|c|}{$\begin{array}{c}\text { Arrhenatherion } \\
\text { elatioris } \\
298\end{array}$} & \multicolumn{2}{|c|}{$\begin{array}{l}\text { Cynosurion } \\
\text { cristati } \\
202\end{array}$} & \multicolumn{2}{|c|}{$\begin{array}{c}\text { Chrysopogono - } \\
\text { Danthonion } \\
10\end{array}$} & \multicolumn{2}{|c|}{$\begin{array}{c}\text { Cirsio- } \\
\text { Brachypodion } \\
122\end{array}$} & \multicolumn{2}{|c|}{$\begin{array}{l}\text { Festucion } \\
\text { valesiacae } \\
236\end{array}$} \\
\hline & Phi & $\%$ & Phi & $\%$ & Phi & $\%$ & Phi & $\%$ & Phi & $\%$ \\
\hline Poa pratensis & 59 & 89 & 30 & 62 & --- & --- & --- & 14 & --- & --- \\
\hline Vicia grandiflora & 57 & 60 & 24 & --- & --- & --- & --- & --- & --- & 1 \\
\hline Vicia cracca & 56 & 58 & --- & 21 & --- & --- & --- & 2 & --- & 1 \\
\hline Geranium dissectum & 49 & 31 & --- & 1 & --- & --- & --- & --- & --- & --- \\
\hline Arrhenatherum elatius & 45 & 62 & 23 & 44 & --- & 9 & --- & 1 & --- & 2 \\
\hline Taraxacum sec. Ruderalia & 45 & 63 & 39 & 58 & --- & --- & --- & --- & --- & --- \\
\hline Festuca pratensis & 45 & 72 & 42 & 69 & --- & --- & --- & 10 & --- & 1 \\
\hline Dactylis glomerata & 42 & 73 & 30 & 62 & --- & 18 & --- & 11 & --- & 1 \\
\hline Trifolium campestre & 41 & 55 & --- & 25 & --- & 18 & --- & 2 & --- & 6 \\
\hline Trisetum flavescens & 40 & 42 & --- & 15 & --- & 9 & --- & --- & --- & 3 \\
\hline Convolvulus arvensis & 39 & 74 & 20 & 56 & --- & 9 & --- & 18 & --- & 26 \\
\hline Myosotis arvensis & 37 & 26 & --- & 7 & --- & --- & --- & --- & --- & 2 \\
\hline Vicia tetrasperma & 36 & 38 & 13 & 23 & --- & --- & --- & --- & --- & 6 \\
\hline Dipsacus laciniatus & 35 & 22 & 1 & 6 & --- & --- & --- & --- & --- & --- \\
\hline Silene vulgaris & 35 & 17 & --- & 1 & --- & --- & --- & --- & --- & --- \\
\hline Cirsium arvense & 34 & 29 & 6 & 12 & --- & --- & --- & 2 & --- & 2 \\
\hline Galium album & 34 & 23 & 4 & 8 & --- & --- & --- & --- & --- & 1 \\
\hline Crepis biennis & 33 & 40 & 30 & 37 & --- & --- & --- & --- & --- & --- \\
\hline Tragopogon dubius & 33 & 21 & --- & 4 & --- & --- & --- & --- & --- & 3 \\
\hline Trifolium striatum & 32 & 24 & 9 & 12 & --- & --- & --- & --- & --- & --- \\
\hline Elymus repens & 31 & 54 & 5 & 31 & --- & 9 & --- & 20 & --- & 17 \\
\hline Lathyrus aphaca & 31 & 14 & --- & 1 & --- & --- & --- & --- & --- & 1 \\
\hline Salvia nemorosa & 31 & 31 & --- & 2 & --- & 9 & --- & 11 & --- & 3 \\
\hline Lathyrus nissolia & 30 & 20 & 1 & 6 & --- & --- & --- & 1 & --- & 1 \\
\hline Ranunculus polyanthemos & 30 & 28 & 18 & 21 & --- & --- & --- & --- & --- & 1 \\
\hline Holcus lanatus & --- & 7 & 63 & 54 & --- & --- & --- & --- & --- & --- \\
\hline Cynosurus cristatus & --- & 20 & 62 & 82 & --- & 27 & --- & 2 & --- & 1 \\
\hline Agrostis capillaris & --- & 4 & 57 & 85 & --- & 45 & --- & 22 & --- & 1 \\
\hline Leontodon autumnalis & --- & 9 & 50 & 45 & --- & --- & --- & 7 & --- & --- \\
\hline Deschampsia caespitosa & --- & 5 & 49 & 35 & --- & --- & --- & --- & --- & 1 \\
\hline Rumex acetosa & --- & 14 & 48 & 54 & --- & 18 & --- & --- & --- & 1 \\
\hline Cerastium holosteoides & 18 & 30 & 46 & 50 & --- & --- & --- & --- & --- & 1 \\
\hline Stellaria graminea & 18 & 41 & 45 & 64 & --- & 18 & --- & --- & --- & 1 \\
\hline Ranunculus acris & 12 & 36 & 44 & 64 & --- & 18 & --- & 4 & --- & 5 \\
\hline Centaurea phrygia & --- & 1 & 43 & 24 & --- & --- & --- & --- & --- & --- \\
\hline Trifolium repens & 29 & 56 & 42 & 68 & --- & 9 & --- & 11 & --- & 3 \\
\hline Alopecurus pratensis & 21 & 38 & 42 & 54 & --- & 9 & --- & --- & --- & 1 \\
\hline Prunella vulgaris & --- & 7 & 40 & 43 & --- & 9 & --- & 11 & --- & 1 \\
\hline Rosa canina & 11 & 18 & 39 & 35 & --- & --- & --- & --- & --- & --- \\
\hline Phleum pratense & --- & 8 & 38 & 34 & --- & --- & --- & 8 & --- & 1 \\
\hline Trifolium pratense & 28 & 63 & 38 & 72 & 1 & 36 & --- & 3 & --- & 2 \\
\hline Leontodon hispidus & 22 & 43 & 37 & 55 & --- & 18 & --- & 1 & --- & 1 \\
\hline
\end{tabular}


Number of relevés

Rhinanthus rumelicus

Trifolium dubium

Trifolium patens

Cirsium canum

Carum carvi

Achillea millefolium

Trifolium hybridum

Sanguisorba officinalis

Festuca rubra agg.

Carex hirta

Lolium perenne

Danthonia alpina

Linum catharticum

Briza media

Polygala vulgaris

Carex tomentosa

Chrysopogon gryllus

Thymus callieri

Anthoxanthum odoratum

Scorzonera hispanica

Orchis morio

Luzula multiflora

Dorycnium herbaceum

Trifolium montanum

Filipendula vulgaris

Koeleria nutidula

Hieracium praealtum

Campanula sparsa

Prunus spinosa

Avenula compressa

Phleum phleoides

Asperula cynanchica

Thymus longicaulis

Brachypodium pinnatum

Potentilla cinerea

Scabiosa columbaria

Veronica austriaca

Bromus riparius

Hypericum linarioides

Primula veris

Minuartia viscosa

Sesleria latifolia

Asperula purpurea

Pimpinella tragium

Trifolium alpestre

Artemisia chamaemelifolia

Seseli peucedanoides

Koeleria macrantha

Carlina acanthifolia

Cerastium banaticum

Carex humilis

Festuca dalmatica

298

$15 \quad 41$

$\begin{array}{ll}15 & 41 \\ --- & 4\end{array}$

$---4$

8

$9 \quad 12$

$31 \quad 84$

$18 \quad 21$

$---1$

$---27$

$3 \quad 8$

$25 \quad 29$

--- 2

--- 2

$--\quad 9$

$\begin{array}{cc}-- & 4 \\ --- & --\end{array}$

$\begin{array}{ll}--- & -- \\ --- & 1\end{array}$

$\begin{array}{ll}-- & \\ -- & 2\end{array}$

$---13$

$\begin{array}{ll}-- & -- \\ --- & ---\end{array}$

$\begin{array}{ll}--- & --- \\ --- & ---\end{array}$

-- $\quad 2$

$\begin{array}{ll}--- & 4 \\ --- & 5\end{array}$

$---\quad--$

$--\quad 12$

$---$

$\begin{array}{ll}-- & 1 \\ -- & 2\end{array}$

$---$

$\begin{array}{cc}--- & 1 \\ --- & --\end{array}$

-- 3

$\begin{array}{ll}-- & -- \\ --- & --\end{array}$

$---$

--- ---

$\begin{array}{cc}--- & - \\ --- & 1\end{array}$

$\begin{array}{cccccc}---- & 1 & -- & -- \\ --- & -- & -- & -- & -- & --\end{array}$

$\begin{array}{llllll}--- & -- & -- & -- & -- & --\end{array}$

\begin{tabular}{llllll}
-- & -- & -- & -- & -- & -- \\
\hline
\end{tabular}

$\begin{array}{cccccc}--- & --- & -- & --- & --- & -- \\ --- & --- & --- & 3 & --- & 36\end{array}$

$\begin{array}{cccccc}-- & -- & -- & -- & -- & -- \\ - & -- & -- & -\end{array}$

$\begin{array}{cccccc}--- & -- & -- & -- & -- & --\end{array}$

$\begin{array}{cccccc}--- & 4 & --- & 2 & -- & -- \\ --- & 3 & --- & --- & -- & 18\end{array}$

$\begin{array}{cccccc}--- & 3 & -- & -- & -- & 18 \\ --- & --- & --- & --- & -- & 9\end{array}$

$\begin{array}{cccccc}--- & -- & -- & -- & -- & --\end{array}$

$\begin{array}{llll}-- & 8 & -- & 5\end{array}$

$32 \quad 85$

$32 \quad 29$

$31 \quad 14$

$30-21$

$30 \quad 32$

$---41$

$---11$

$---1$

$30 \quad 74$

$\begin{array}{ll}--- & 1 \\ --- & 1\end{array}$

$---\quad---$

$\begin{array}{lr}-- & 8 \\ - & 11\end{array}$

$---34$

$---\quad--$

$15 \quad 45$
122

\begin{tabular}{lll}
\multicolumn{3}{c}{236} \\
--- & --- & 7
\end{tabular}

$\begin{array}{llll}-- & -- & -- & 1\end{array}$

$\begin{array}{llll}--- & 1 & -- & --\end{array}$

$\begin{array}{llll}--- & --- & --- & -- \\ --- & --- & --- & --\end{array}$

$\begin{array}{llll}-- & 22 & -- & 35\end{array}$

$---\quad 20$ $---\quad--$

$\begin{array}{cc}--- & -- \\ --- & 1\end{array}$

$---1$

$---\quad--$

$---\quad 3$

$---4$

$---\quad 2$

$---1$

$---1$

$---9$

$41 \quad 68$

$---13$

$---\quad---$

$---\quad 2$

$---\quad--$

$---\quad--$

$---\quad 2$

$---\quad 8$

$27 \quad 39$

$---\quad 20$

$---\quad---$

$\begin{array}{ll}3 & 11\end{array}$

$3 \quad 11$

$---5$

$---14$

$---\quad 2$

$--\quad 5$

$---13$

$---6$

$---6$

$---2$

$---1$

$---1$

$---1$

$---\quad--$

$---\quad 15$

$---4$

$\begin{array}{ll}-- & 4 \\ -- & 8\end{array}$

$\begin{array}{llll}45 & 25 & --- & -- \\ 45 & 28 & --- & 3\end{array}$

$\begin{array}{llll}44 & 32 & -- & 1\end{array}$

$\begin{array}{llll}44 & 55 & 2 & 22\end{array}$

$\begin{array}{llll}43 & 34 & -- & 3\end{array}$

$\begin{array}{llll}39 & 21 & --- & 2\end{array}$

$\begin{array}{llll}37 & 66 & -- & 32\end{array}$ 


\begin{tabular}{|c|c|c|c|c|c|c|c|c|c|c|}
\hline \multirow{2}{*}{$\frac{\text { Number of relevés }}{\text { Inula salicina }}$} & \multicolumn{2}{|c|}{298} & \multicolumn{2}{|c|}{202} & \multicolumn{2}{|c|}{10} & \multicolumn{2}{|c|}{122} & \multicolumn{2}{|c|}{236} \\
\hline & --- & 1 & --- & 4 & --- & 9 & 37 & 30 & --- & --- \\
\hline Hieracium pilosella & --- & 1 & --- & 1 & 1 & 18 & 37 & 45 & 4 & 21 \\
\hline Achillea setacea & --- & --- & --- & --- & 5 & 18 & 37 & 40 & --- & 13 \\
\hline Chamaecytisus calcareus & --- & --- & --- & --- & 3 & 9 & 36 & 26 & --- & 1 \\
\hline Fragaria viridis & --- & 4 & --- & 2 & 2 & 18 & 36 & 43 & --- & 2 \\
\hline Chamaespartium sagittale & --- & 1 & --- & 1 & 26 & 36 & 35 & 43 & --- & 2 \\
\hline Polygala major & --- & 1 & --- & --- & --- & --- & 35 & 20 & --- & 4 \\
\hline Veratrum nigrum & --- & --- & --- & --- & --- & --- & 34 & 15 & --- & --- \\
\hline Globularia aphyllanthes & --- & --- & --- & --- & --- & --- & 34 & 19 & --- & 4 \\
\hline Cruciata glabra & --- & --- & --- & 1 & 4 & 9 & 33 & 24 & --- & --- \\
\hline Galium lovcense & --- & --- & --- & --- & 15 & 27 & 33 & 40 & --- & 12 \\
\hline Corothamnus procumbens & --- & --- & --- & --- & --- & --- & 30 & 11 & --- & --- \\
\hline Centaurea triumfetti & --- & --- & --- & --- & --- & --- & 30 & 11 & --- & --- \\
\hline Avenula pubescens & -- & 2 & --- & 3 & -- & -- & 30 & 18 & --- & 1 \\
\hline Astragalus onobrychis & -- & 1 & --- & & -- & -- & -- & 2 & 75 & 66 \\
\hline Medicago minima & --- & 4 & --- & & --- & --- & --- & 1 & 44 & 30 \\
\hline Eryngium campestre & --- & 26 & --- & 16 & --- & 36 & --- & 33 & 44 & 81 \\
\hline Poa angustifolia & --- & --- & --- & --- & --- & 18 & --- & 10 & 42 & 44 \\
\hline Centaurea sp. & --- & --- & --- & --- & --- & -- & --- & 7 & 42 & 29 \\
\hline Dichanthium ischaemum & --- & --- & --- & --- & --- & --- & --- & 3 & 39 & 23 \\
\hline Veronica verna & --- & --- & --- & --- & --- & --- & --- & --- & 38 & 18 \\
\hline Teucrium polium & --- & --- & --- & --- & --- & -- & --- & 1 & 37 & 18 \\
\hline Medicago falcata & --- & 10 & --- & 2 & --- & --- & 14 & 28 & 37 & 45 \\
\hline Trifolium dalmaticum & --- & --- & --- & --- & --- & --- & --- & 2 & 37 & 19 \\
\hline Trifolium aureum & --- & 1 & --- & 4 & --- & --- & --- & 4 & 34 & 23 \\
\hline Erysimum diffusum & -- & 1 & --- & --- & -- & -- & -- & -- & 33 & 15 \\
\hline Rosa sp. & --- & --- & --- & --- & --- & 9 & --- & 7 & 33 & 28 \\
\hline Alyssum minus & --- & --- & --- & --- & --- & -- & 7 & 10 & 32 & 22 \\
\hline Thesium arvense & --- & --- & --- & --- & --- & --- & --- & 2 & 31 & 14 \\
\hline Verbascum phlomoides & --- & --- & --- & --- & --- & -- & --- & --- & 31 & 12 \\
\hline Convolvulus cantabrica & --- & 1 & --- & --- & --- & --- & --- & 1 & 30 & 14 \\
\hline Stipa eriocaulis & --- & --- & --- & --- & --- & -- & --- & -- & 30 & 11 \\
\hline Festuca rupicola & --- & 3 & --- & 3 & -- & -- & --- & --- & 30 & 18 \\
\hline
\end{tabular}

Table 2: Attributes of the studied vegetation units. The measures of $\beta$-diversity, Sharpness and Uniqueness indices were calculated on the basis of 100 randomly selected relevés per group, in order to obtain comparable values between the different groups; the same attributes are not given for Chrysopogono-Danthonion alliance because it was only represented by small number of relevés.

Tabela 2: Značilnosti proučevane vegetacije. Vrednost $\beta$ diverzitete, indeksa Sharpness in Uniqueness smo izračunali na osnovi 100 naključno izbranih popisov na skupino, da bi zagotovili primerljive vrednosti med različnimi skupinami. Vse značilnosti niso prikazane za zvezo Chrysopogono-Danthonion, saj je vzorčena z majhnim številom popisov.

\begin{tabular}{|c|c|c|c|c|c|c|c|}
\hline Alliance & $\begin{array}{c}\text { Number } \\
\text { of } \\
\text { relevés }\end{array}$ & $\begin{array}{c}\text { Total } \\
\text { species } \\
\text { number }\end{array}$ & $\begin{array}{c}\text { Average } \\
\text { species } \\
\text { number }\end{array}$ & $\begin{array}{c}\text { Average } \\
\text { Whittaker } \\
\text { beta- } \\
\text { diversity }\end{array}$ & $\begin{array}{c}\text { Average } \\
\text { Shannon } \\
\text { index }\end{array}$ & $\begin{array}{l}\text { Sharpness } \\
\text { index }\end{array}$ & $\begin{array}{l}\text { Uniqueness } \\
\text { index }\end{array}$ \\
\hline Arrhenatherion elatioris & 298 & 275 & 35.59 & 7.96 & 3.10 & 6.20 & 0.92 \\
\hline Cynosurion cristati & 202 & 269 & 38.89 & 7.08 & 3.26 & 4.70 & 0.92 \\
\hline Chrysopogono-Danthonion & 10 & 111 & 33.40 & - & 2.96 & - & - \\
\hline Cirsio-Brachypodion & 105 & 210 & 33.95 & 8.28 & 2.87 & 19.97 & 1.00 \\
\hline Festucion valesiacae & 231 & 326 & 27.16 & 12.60 & 2.54 & 2.71 & 0.88 \\
\hline
\end{tabular}

